\title{
PENENTUAN WAKTU OPTIMUM DALAM PEMBUATAN BIOETANOL DARI BONGGOL PISANG TANDUK(Musa paradisiaca formatypisa) MELALUI FERMENTASI
}

\author{
Determination of the Optimum Time in Production of Bioethanol from \\ Banana(Musa paradisiaca formatypisa) Tuber through Fermentation
}

\author{
*Eka Lilis Setiawati, Siang Tandi Gonggo, dan Paulus Hengky Abram \\ Pendidikan Kimia/FKIP - Universitas Tadulako, Palu - Indonesia 94118 \\ Received 07 June 2016, Revised 07 July 2016, Accepted 08 August 2016
}

\begin{abstract}
Banana tuber contains $76 \%$ starch as a source of organic material that can be changed to bioethanol which is an alternative of fuel oil. This study aimed to determine the optimum time of fermentation in the process of producing bioethanol from banana (Musa paradisiaca formatypisa) tuber. In this study the fermentation of banana tuber is determinedusing saccharomyces cereviseae with the variation time of 3 , 4, 5, 6, 7, 8 and 10 days. The stages carried out in this study were preliminary or sample preparation, delignification, hydrolysis, fermentation and separation. Bioethanol from the fermented ricestraw was analyzed using alcoholmeter. The content of bioethanol product increased on days 3 to 7 and reach the optimum on the day 7 which was $8.90 \%$, where on the day 8 and 10 decreased the ethanol content.
\end{abstract}

Keywords: Bioethanol, musa paradisiaca formatypisa,fermentation, optimum time

\section{Pendahuluan}

Krisis energi dunia merupakan masalah yang sedang dihadapi banyak negara termasuk Indonesia. Krisis ini terjadi akibat ketergantungan pemenuhan energi bahan bakar dunia yang berasal dari bahan bakar fosil. Padahal bahan bakar fosil ini merupakan sumber daya alam yang tidak dapat diperbaharui. Oleh karena itu, sangat diperlukan usaha-usaha pencarian sumber energi alternatif untuk mengatasi masalah krisis energi (Haryono, dkk., 2010). Mulyono, dkk., (2011) menyatakan bahwa Indonesia saat ini menghadapi permasalahan yang cukup serius berkaitan bahan bakar fosil, termasuk premium. Usaha yang dilakukan Pemerintah Republik Indonesia untuk mengatasi hal tersebut dengan memprogramkan suatu rancangan yaitu menggunakan limbah-limbah pertanian sebagai pengganti premium atau yang dikenal dengan bioetanol.Bioetanol adalah etanol yang dibuat dari biomassa (tanaman) melalui proses biologi (enzimatik atau fermentasi). Bahan baku

\section{*Correspondence:}

Eka Lilis

Program Studi Pendidikan Kimia, Fakultas Keguruan dan

Ilmu Pendidikan, Universitas Tadulako

email: ehka_v@yahoo.com

Published by Universitas Tadulako 2016 bioetanol dapat berasal dari biomassa sumber pati (jagung, ubi kayu, sorgun, dan lain-lain), sumber gula (molasses, nira tebu, nira kelapa, dan nira dari berbagai tanaman lain), dan sumber selulosa (onggok, jerami padi, ampas tebu, tongkol jagung, dan lain-lain sebagainya) (Mulyono, dkk., 2011).

Salah satu hasil buangan tanaman pisang adalah bonggol pisang. Bonggol pisang merupakan bagian bawah batang tanaman pisang yang berada di bawah permukaan tanah. Tepung bonggol pisang, mengandung pati (karbohidrat) sebesar 66,2\%, serat kasar $10,23 \%$ dan protein 5,88. Berdasarkan potensi nutrisi bahan baku tersebut, bonggol pisang dapat dimanfaatkan sebagai salah satu bahan bakar alternatif yaitu bioetanol. Secara kuantitatif, potensi bonggol pisang di Indonesia dapat dihitung berdasarkan luas kebun pisang pada tahun 2005 seluas 92.307,6 Ha dengan produksi sebesar 9.460.928 ton/ tahun. Produksi limbah tanaman pisang mencapai 8.676 .557 ton/tahun dimana $40 \%$ atau 3.470.623 ton/tahun merupakan bonggol pisang(Badan Penelitian Pertanian, 2005).

Menurut Slametryadi (1996) dari semua manfaat pisang yang paling banyak diketahui penduduk hanya sebatas buahnya saja, 
sehingga setelah diambil buahnya, tanaman pisang (bonggol) tidak mempunyai nilai yang berharga lagi, hanya membusuk. Bonggol pisang memiliki komposisi $76 \%$ pati, 20\% air, sisanya adalah protein dan vitamin (Yuanita, dkk., 2008). Potensi kandungan pati bonggol pisang yang besar dapat dimanfaatkan sebagai bahan alternatif bahan bakar yaitu, bioetanol. $\mathrm{Hal}$ ini karena bonggol pisang memiliki kadar pati yang tinggi, potensi hasil yang tinggi, selain itu umur panen dan usaha tani lebih fleksibel (Prihandana, 2007).

\section{METODE}

\section{Alat dan Bahan}

Alat-alat yang digunakan pada penelitian ini adalah neraca analitik, erlenmeyer, gelas kimia, labu ukur, gelas ukur, pipet tetes, corong, penangas listrik, $\mathrm{pH}$ meter, batang pengaduk, aluminium foil, kertas saring, ayakan 40 mesh, magnet stirrer, oven, blender, pompa vakum, 1 set evaporator, dan alkohol meter. Sedangkan bahan yang digunakan yaitu sampel bonggol pisang tanduk (Musa paradisiaca formatypisa), $\mathrm{HCl}($ Merck), ragi (Sacharomyces cerevisia), $\left(\mathrm{NH}_{2}\right)_{2} \mathrm{CO}$ (urea)(Merck), $\mathrm{NaOH}$ (Merck), aquades $\left(\mathrm{H}_{2} \mathrm{O}\right)$ dan $\left(\mathrm{NH}_{4}\right)_{2} \mathrm{SO}_{4}$ (ammonium sulfat) (MerckK GaA).

\section{Cara Kerja}

\section{Tahap Pendahuluan}

Bonggol pisang diambil di Desa Ongka, Kecamatan Parigi Moutong, kemudian dikupas dan dibersihkan dari kotorannya. Bonggol pisang kemudian dipotong-potong menjadi bagian-bagian yang lebih kecil. Selanjutnya bonggol pisang dicuci dengan air dan kemudian dikeringkan dengan bantuan sinar matahari hingga kering. Bonggol pisang yang telah kering ditimbang sebanyak $2 \mathrm{~kg}$, setelah itu, digiling dengan blender dan diayak dengan menggunakan ayakan 40 mesh.

\section{Tahap Delignifikasi}

Delignifikasi dilakukan dengan mengambil sebanyak 200 gram serbuk bonggol pisang hasil pengayakan kemudian ditambahkan $2700 \mathrm{~mL}$ aquades dan $300 \mathrm{~mL} \mathrm{NaOH} 2 \mathrm{M}$ ke dalam erlenmeyer. Setelah itu, dipanaskan dan diaduk dengan magnetikstirrer selama 2,5 jam pada suhu $80^{\circ} \mathrm{C}$. Selanjutnya larutan dipisahkan dengan cara menyaringnya dengan menggunakan kertas saring. Residu yang diperoleh dioven pada suhu $100^{\circ} \mathrm{C}$ selama 2 jam kemudian digerus hingga halus dengan menggunakan lumpang dan alu. Setelah itu, diayak menggunakan ayakan 40 mesh.

\section{TahapHidrolisis}

Pada tahap ketiga ini pati dihidrolisis menjadi glukosa. Sampel bonggol pisang70 gram ditambahkan $700 \mathrm{~mL}$ larutan $\mathrm{HCl} \mathrm{15 \% .}$ Selanjutnya dimasukkan kedalam gelas kimia dan dipanaskan pada suhu $100^{\circ} \mathrm{C}$ selama 2,5 jam. Hasil hidrolisis didinginkan pada suhu kamar kemudian larutan sampel disaring menggunakan kertas saring.

\section{Tahap Fermentasi}

Proses fermentasi dilakukan dengan mengambil $770 \mathrm{~mL}$ larutan hasil hidrolisis. Setelah itu ditambahkan larutan $\mathrm{NaOH} 6$ $\mathrm{M}$ hingga $\mathrm{pH}$-nya menjadi 5. Kemudian larutan tersebut ditambahkan dengan 28 gram padatan $\left(\mathrm{NH}_{4}\right)_{2} \mathrm{SO}_{4}$ (ammonium sulfat) dan menambahkan 28 gram $\left(\mathrm{NH}_{2}\right)_{2} \mathrm{CO}$ (urea). Selanjutnya dipasteurisasi pada suhu $80^{\circ} \mathrm{C}$ selama 15 menit. Kemudian ditambahkan dengan ragi roti (saccharomyces cereviseae) sebanyak 28 gram. Sebanyak $70 \mathrm{~mL}$ larutannya diukur dimasukkan ke dalam masing-masing erlenmeyer. Setelah itu, ditutup dengan aluminium foil dan dilakukan pendiaman dengan variasi waktu yaitu 3, 4, 5, 6, 7, 8 dan 10 hari pada suhu $30^{\circ} \mathrm{C}$.

\section{TahapPemisahan}

Proses pemisahan dilakukan dengan memasukkan hasil fermentasi kedalam erlenmeyer dan dipasang pada rangkaian alat evaporator. Pada proses ini dilakukan pemanasan pada suhu $80^{\circ} \mathrm{C}$. Kemudian masingmasing larutan hasil evaporasi ditentukan kadar alkohol dengan menggunakan alkoholmeter.

\section{Hasil dan Pembahasan}

Hasil persiapan sampel menunjukkan bahwa terjadinya perubahan warna bonggol pisang dari putih menjadi berwarna cokelat muda yang terjadi ketika pengeringan sampel. Perubahan warna tersebut disebabkan karena zat warna alami pada bahan tidak tahan terhadap suhu tinggi (Buckle, dkk., 1987). Selanjutnya sampel tersebut digunakan untuk proses delignifikasi atau proses penghilangan lignin.

Proses delignifikasi penting dilakukan sebelum melakukan proses hidrolisis, karena lignin merupakan polimer yang memiliki dinding yang kokoh sehingga dapat menghambat penetrasi suatu asam atau enzim 
sebelum proses hidrolisis berlangsung. Selain itu, dapat menghambat pertumbuhan mikroba dalam proses fermentasi (Gunam, dkk., 2010). Delignifikasi juga harus dapat menghalangi terbentuknya inhibitor pada hidrolisis berikutnya dan selama proses fermentasi, menghalangi kehilangan karbohidrat, dan biaya yang efektif (Octavia, dkk., 2011). Proses delignifikasi dalam penelitian ini menggunakan larutan $\mathrm{NaOH}$ sebagai bahan yang berperan dalam pembebasan lignin. Karena natrium hidroksida merupakan senyawa delignifikasi (pretreatment) yang lebih efektif. $\mathrm{NaOH}$ dapat menghilangkan senyawa amorf seperti lignin dan hemiselulosa yang terdapat pada sampel bonggol pisang (Fachry, dkk., 2013). Proses delignifikasi ini menyebabkan perubahan warna pada sampel bonggol pisang dari coklat menjadi coklat tua dan massanya mengalami penurunan dari 200 gram menjadi 180 gram.

Bonggol pisang dari hasil delignifikasi kemudian dihidrolisis tujuannya yaitu untuk menentukan jumlah glukosa yang dihasilkan dan untuk mengubah polisakarida (pati) menjadi monosakarida (glukosa)(Sukmawati $\&$ Milati, 2009). Prinsip hidrolisis pati adalah pemutusan rantai polimer pati menjadi unit-unit dekstrosa atau monosakarida yaitu glukosa $\left(\mathrm{C}_{6} \mathrm{H}_{12} \mathrm{O}_{6}\right)$ (Assegaf, 2009).Pemutusan ikatan pada pati atau karbohidrat menjadi glukosa dapat menggunakan beberapa metode hidrolisis diantaranya yaitu metode kimiawi (hidrolisis asam) atau enzimatik (Usmana, dkk., 2012). Proses hidrolisis dalam penelitian ini menggunakan asam klorida (HCl 15\%)(Mussatto \& Teixeira, 2010). Penambahan asam klorida pekat bertujuan untuk menghidrolisis pati karena pati dapat dihidrolisis sempurna dengan menggunakan asam sehingga menghasilkan glukosa. Setelah itu larutan dipanaskan, pemanasan bertujuan untuk mempercepat terjadinya hidrolisis. Semakin lama pemanasan, maka semakin banyak pati yang akan terhidrolisis menjadi monosakaridanya yakni glukosa (Barokah \& Abtokhi, 2013).

Proton $\left(\mathrm{H}^{+}\right)$dari senyawa $\mathrm{HCl}$ pada proses hidrolisis akan mengubah bonggol pisang menjadi suatu gugus radikal bebas. Gugus radikal bebas tersebut kemudian akan berikatan dengan gugus $\mathrm{OH}^{-}$dari $\mathrm{H}_{2} \mathrm{O}$ dan menghasilkan glukosa. Pada saat kebutuhan $\mathrm{H}^{+}$dari $\mathrm{HCl}$ telah mencukupi pembentukan gugus radikal bebas dari bonggol pisang maka glukosa yang dihasilkan maksimal (Assegaf, 2009). Namun, konsentrasi suatu larutan penghidrolisis menentukan banyak tidak glukosa yang dihasilkan. Jika dilakukan penambahan konsentrasi suatu larutan asam terlalu banyak, maka glukosa yang dihasilkan akan berkurang. Hal ini disebabkan banyaknya pembentukan gugus radikal bebas, akan tetapi penambahan konsentrasi tersebut menyebabkan semakin sedikitnya molekul air dalam larutan hidrolisis. Sehingga berkurangnnya kebutuhan gugus $\mathrm{OH}^{-}$sebagai pengikat gugus radikal bebas dan glukosa yang dihasilkan pula menjadi sedikit (Hikmiyati \& Novica, 2008). Proses hidrolisis tersebut seperti pada Gambar 1.

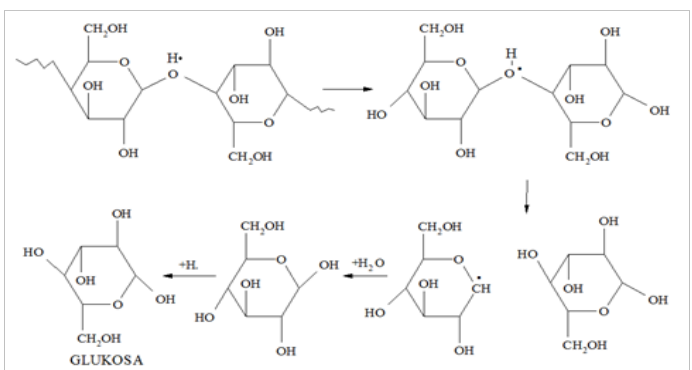

Gambar 1. Mekanisme Reaksi Hidrolisis Pati Menjadi Glukosa (Xiang, dkk., 2003).

Mekanismeyang terjadi pada reaksi hidrolisis pati menjadi glukosa yaitu proton dari asam akan berinteraksi secara cepat dengan ikatan glikosidik oksigen pada dua unit gula sehingga akan membentuk asam konjugasi. Keberadaan asam konjugasi menyebabkan konformasi tidak stabil sehingga terjadi pemutusan ikatan $\mathrm{C}-\mathrm{O}$ dan membebaskan asam konjugasi pada konformasi yang tidak stabil. Keberadaan air pada sistem akan menyebabkan $\mathrm{OH}$ dari air berikatan dengan ion karbonium sehingga membebaskan gula dan proton. Proton yang terbentuk akan berinteraksi secara cepat dengan ikatan glikosidik oksigen pada dua unit gula yang lain. Proses tersebut terjadi secara kontinyu sampai semua molekul patiterhidrolisis menjadi glukosa (Xiang, dkk., 2003).

Tahap selanjutnya yaitu fermentasi menggunakan ragi saccharomyces cerevisiae yang merupakan sumber mikroorganisme untuk menghasilkan etanol. Namun, sebelum penambahan ragi pada larutan sampel terlebih dahulu $\mathrm{pH}$ dari sampel tersebut dibuat menjadi $\mathrm{pH} 5$. Hal ini sesuai dengan pendapat Roukas, (1994) bahwa kisaran pertumbuhan mikroba saccharomyces cerevisiae yaitu $\mathrm{pH}$ 3,5-6,5 dan pada $\mathrm{pH} 4,5$ adalah kondisi $\mathrm{pH}$ yang maksimal dapat dicapai. Jika pada kondisi basa mikroba tersebut tidak dapat tumbuh. saccharomyces cerevisiae merupakan mikroorganisme yang paling banyak digunakan pada fermentasi alkohol karena dapat berproduksi tinggi, tahan terhadap kadar alkohol yang tinggi, tahan 
terhadap kadar gula yang tinggi dan tetap aktif melakukan aktivitasnya pada suhu $4-32^{\circ} \mathrm{C}$ (Kartika, dkk., 1992). Hal ini menunjukan bahwa apabila pada suhu yang terlalu rendah, maka proses fermentasi akan berlangsung secara lambat. Sedangkan pada suhu yang terlalu tinggi menyebabkan mikroba saccharomyces cerevisiae akan mati sehingga proses fermentasi tidak dapat berlangsung.

Mikroba saccharomyces cerevisiae memiliki beberapa kelebihan dibandingkan mikroba lain seperti kluyveromy fragilis yang juga dapat memproduksi alkohol. Mikroba saccharomyces cerevisiae dapat mengkonversi gula menjadi alkohol lebih cepat dibandingkan mikroba kluyveromy fragilis. saccharomyces cerevisiae dapat menghasilkan alkohol hingga 2\% dalam 72 jam, sedangkan mikroba kluyveromy fragilis membutuhkan waktu yang cukup lama untuk menghasilkan kadar alkohol hingga $2 \%$ yaitu selama 1 minggu (O'Leary, dkk., 2004). Mikroba saccharomyces cerevisiae dapat mengkorversi gula menjadi etanol karena adanya enzim invertase dan enzim zimase yang dihasilkan oleh mikroba tersebut. Kedua enzim tersebut mikroba saccharomyces cerevisiae memiliki kemampuan untuk mengkonversi gula dari kelompok monosakarida maupun dari kelompok disakarida. Jika gula di dalam substrat adalah kelompok disakarida maka enzim invertase akan menghidrolisis disakarida menjadi monosakarida. Setelah itu, enzim zimase akan mengkonversi monosakarida tersebut menjadi alkohol dan karbondioksida (Judoamidjojo, dkk., 1992).

Tahap selanjutnya yaitu proses evaporasi yang bertujuan untuk memisahkan suatu cairan dari campurannya berdasarkan titik didihnya. Senyawa yang menguap terlebih dahulu dalam proses ini adalah etanol karena titik didih etanol murni yaitu $78^{\circ} \mathrm{C}$ lebih rendah dibandingkan dengan pelarut air yaitu $100^{\circ} \mathrm{C}$ (kondisi standar). Hasil evaporasi kemudian dilakukan pengukuran kadar alkohol dengan menggunakan alkoholmeter. Metode penggunaan alat alkoholmeter sangat mudah dengan cara memasukkan sampel etanol hasil evaporasi ke dalam gelas ukur, kemudian celupkan alat alkoholmeter ke gelas ukur dan catat kadar etanol yang terbaca.

Hasil penentuan kadar bioetanol dari hasil evaporasi pada penelitian ini disajikan pada Tabel 1. Produksi etanol pada hari ke-3, ke-4, ke-5 dan ke-6 yang dihasilkan belum optimal karena yeast saccharomyces cerevisiae berada pada tahap lag phase. Tahap lag phase merupakan tahap adaptasi mikroba terhadap lingkungan dan exponential phase adalah tahap dimana mikroba mulai melakukan pertumbuhan, sedangkan pada saat hari ke-7 mikroba (saccharomyces cerevisiae) memiliki aktivitas paling besar atau berada pada logarithmic phase. Logarithmic phase merupakan fase untuk pembentukan produk etanol yang terbesar. Selanjutnya pada hari ke-8 dan ke-10 mikroba mengalami stationary phase maka akan berlanjut menjadi death phase/ fase kematian. Hal ini sesuai dengan kurva pertumbuhan Tabel 1 Kadar Bioetanol Hasil Fermentasi

\begin{tabular}{ccc}
\hline $\begin{array}{c}\text { Lama Fermentasi } \\
\text { (hari) }\end{array}$ & $\begin{array}{c}\text { Volume Bioetanol } \\
(\mathbf{m L})\end{array}$ & $\begin{array}{c}\text { Kadar Bioetanol } \\
(\%)\end{array}$ \\
\hline $\mathbf{3}$ & 79 & 4,60 \\
$\mathbf{4}$ & 87 & 5,85 \\
$\mathbf{5}$ & 100 & 7,05 \\
$\mathbf{6}$ & 110 & 8,00 \\
$\mathbf{7}$ & 125 & 8,90 \\
$\mathbf{8}$ & 140 & 6,95 \\
$\mathbf{1 0}$ & 165 & 4,00 \\
\hline
\end{tabular}

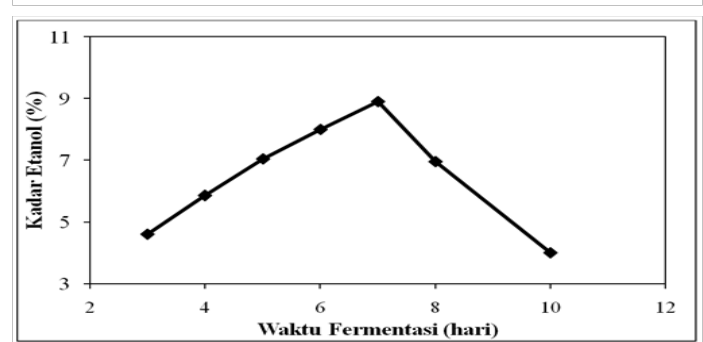

Gambar 2 Grafik Kadar Etanol Hasil Fermentasi

mikroba (Gambar 2).

Gambar 2 menunjukkan bahwa lama waktu fermentasi mempengaruhi kadar etanol yang didapatkan (Warsa, dkk., 2013).Hal ini menunjukkan bahwa kadar etanol hasil fermentasi yang diperoleh mengalami kenaikan dan mencampai optimum pada hari ke-7 yaitu sebanyak $8,90 \%$, sedangkan hari ke- 8 dan 10 mengalami penurunan, karena alkohol telah dikonversi menjadi senyawa lain, misalnya asam karboksilat dan ester (Sari, dkk., 2008). Proses reaksi pembentukan ester seperti pada Gambar 3.

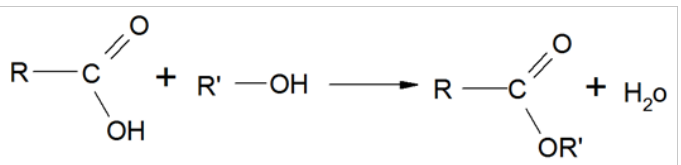

Gambar 3 Reaksi Pembentukan Ester(Sari, dkk., 2008). 
Lama fermentasi dipengaruhi oleh faktorfaktor yang secara langsung maupun tidak langsung berpengaruh terhadap proses fermentasi. Menurut Kunaepah (2008), ada banyak faktor yang mempengaruhi fermentasi antara lain substrat, suhu, $\mathrm{pH}$, oksigen, dan mikroba yang digunakan. Lama fermentasi akan menyebabkan berkurangnya kadar bioetanol. Berkurangnya kadar bioetanol disebabkan karena etanol telah dikonversi menjadi senyawa lain, misalnya $\mathrm{H} 2 \mathrm{O}$ dan ester (Azizah, dkk., 2012). Sehingga volume bioetanol akan mengalami kenaikan. Gambar 4 menunjukkan bahwa volume bioetanol pada hari ke-3 sampai hari ke-10 mengalami kenaikkan. Semakin lama waktu fermentasi terdapat kecenderungan pertambahan volume hasil fermentasi(Hikmivati \& Novica, 2008).

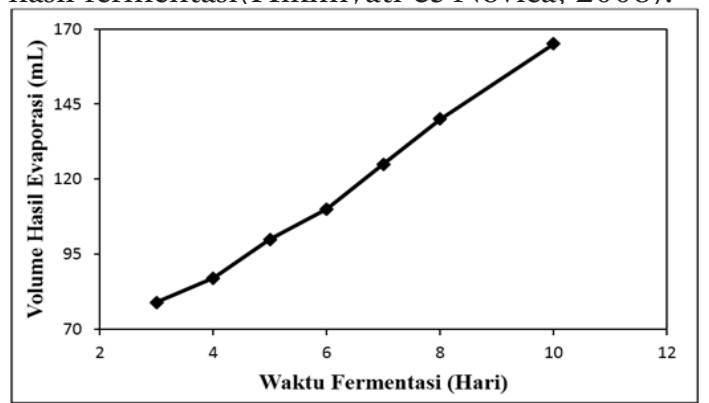

Gambar 4 Volume Bioetanol (mL)

\section{Kesimpulan}

Penelitian ini menunjukkan bahwa kadar etanol yang diperoleh dari bonggol pisang tanduk mengalami kenaikan pada hari ke-3 hingga ke-7 dan mencapai waktu optimum pada hari ke-7 yaitu sebesar $8,90 \%$, kemudian hari ke-8 dan ke-10 mengalami penurunan kadar etanol.

\section{Ucapan Terima Kasih}

Penulis mengucapkan terima kasih kepada Ibu Ida Kesuma Utami selaku pengelola Laboratorium Agroteknologi Fakultas Pertanian Universitas Tadulako yang telah banyak membantu penulis dalam menyelesaikan penelitian ini.

\section{Referensi}

Assegaf, F. (2009). Prospek produksi bioetanol bonggol pisang (musa paradisiacal) menggunakan metode hidrolisis asam dan enzimatis. Univeristas Jenderal Soedirman. $1-28$.
Azizah, N., Baarri, A. N. A., \& Mulyani, S. (2012). Pengaruh lama fermentasi terhadap kadar alkohol, $\mathrm{pH}$, dan produksi gas pada proses fermentasi bioetanol dari whey dengan subtitusi kulit nanas. Jurnal Aplikasi Teknologi Pangan, 1(2), 72-7

Badan Penelitian Pertanian. (2005). Prospek dan arah pengembangan agribisnis pisang. Badan Penelitian dan Pengembangan Pertanian, Departemen Pertanian. Jakarta.

Barokah, Q., \& Abtokhi, A. (2013). Kadar glukosa pada biomassa bonggol pisang melalui paparan radiasi matahari, gelombang mikro dan hidrolisis asam. Jurnal Neutrino, 5(2), 123-132.

Buckle, K. A., Edwards, R. A., Fleet, G. H., \& Wooton, M. (1987). Ilmu pangan. Universitas Indonesia Press: Jakarta.

Fachry, R. A., Astuti, P., \& Puspitasari, T. G. (2013). Pembuatan bioetanol dari limbah tongkol jagung dengan variasi konsentrasi asam klorida dan waktu Fermentasi. Jurnal Tehnik Kimia, 2(19), 60 -69.

Gunam, I. B. W., Buda, K., \& Guna, M. Y. S. (2010). Pengaruh perlakuan delignifikasi dengan larutan $\mathrm{NaOH}$ dan konsentrasi substrat jerami padi terhadap produksi enzim selulase dari aspergillus niger NRRL A-II, 264. Jurnal Biologi, 14(5), 55 - 61.

Haryono, Kurniawan, R., Nurhayani, A., \& Soviyani, D. A. (2010). Pembuatan bioetanol dari bahan berbasis selulosa. Jurnal Institut Nasional, 2(4), 1-7.

Hikmiyati, N., \& Novica, Y. S. (2008). Pembuatan bioetanol dari limbah kulit singkong melalui proses hidrolisa asam dan enzimatis. Jurnal Teknik Kimia, Fakultas Teknik Universitas Diponegoro.

Judoamidjojo, M., Darwis, A. A., \& Sa’id, E. G. (1992). Teknologi fermentasi. Rajawali Press Jakarta.

Kartika, B., Guritno, A. D., Purwadi, D., \& Ismoyowati, D. (1992). Petunjuk evaluasi produk industri hasil pertanian. PAU Pangan 
dan Gizi UGM: Yogyakarta.

Kunaepah, U. (2008). Pengaruh Lama Fermentasi dan Konsentrasi Glukosa terhadap Aktivitas Antibakteri, Polifenol Total dan Mutu Kimia Kefir Susu Kacang Merah. (Tesis), Universitas Diponegoro, Semarang.

Mulyono, A. M. W., Handayani, C. B., Tari, A. I. N., \& Zuprizal. (2011). Fermentasi etanol dari jerami padi. Karya Tulis Ilmiah Lembaga Penelitian dan Pengabdian Kepada Masyarakat Universitas Veteran Bangun Nusantara Sukoharjo.

Mussatto, S. I., \& Teixeira, J. A. (2010). Lignocellulose as raw material in fermentation processes. Current research. Technologi and Education Topics in Applied Microbiologi And Microbial Biotechnology A. Mendez-Vilas (Ed). 897-907.

O'Leary, V. S., Green, R., Sullivan, B. C., \& Holsinger, V. H. (2004). Alcohol production by selected yeast strains in lactase hydrolyzed acid whey. Jurnal Biotechnology and Bioengineering, 19(7), 1019 - 1035.

Octavia, S., Soerawidjaja, T. H., Purwadi1, R., \& Putrawan1, I. D. G. A. (2011). Pengolahan awal lignoselulosa menggunakan amoniak untuk meningkatkan perolehan gula fermentasi. Prosiding Seminar Nasional Teknik Kimia "Kejuangan" Pengembangan Teknologi Kimia untuk Pengolahan Sumber Daya Alam Indonesia.

Prihandana. (2007). Bioetanol ubi kayu bahan bakar masa depan. Jakarta: Agromedia.

Roukas, T. (1994). Continuous ethanol productions from carob pod extract by immobilized saccharomycess cerevisiae in a packed bed reactor. Journal Chemistry Technology Biotechnol, 59, 387-393.

Sari, M. I., Noverita, \& Yulneriwarni. (2008). Pemanfaatan jerami padi dan alang-alang dalam fermentasi etanol menggunakan kapang trichoderma viride dan kamir saccharomycess cerevisiae. Jurnal Vis Vitalis, 5(2), 55-62.

Slametryadi, I. K. (1996). Pemanfaatan limbah bonggol pisang sebagai bahan baku pembuatan etanol. Jurusan Pendidikan MIPA. Universitas Tadulako.

Sukmawati, R. F., \& Milati, S. (2009). Pembuatan bioetanol dari kulit singkong. (Skripsi), Universitas Sebelas Maret, Surakarta.

Usmana, A. S., Rianda, S., \& Novia. (2012). Pengaruh volume enzim dan waktu fermentasi terhadap kadar etanol (bahan baku tandan kosong kelapa sawit dengan pretreatment alkali). Jurnal Teknik Kimia, 18(2), 17-25.

Warsa, I. W., Septiyani, F., \& Lisna, C. (2013). Bioetanol dari bonggol pohon pisang. Jurnal Teknik Kimia, 8(1), 37-41.

Xiang, Q., Lee, Y. Y., Pettersson, P. O., \& Torget, R. W. (2003). Heterogeneous aspects of acid hydrolysis of $\alpha$-cellulose. Jurnal Humana Press, 105-108(1), 505 - 514.

Yuanita, Voni, Rahmawati, \& Yulia. (2008). Pabrik sorbitol dari bonggol pisang (musa paradisiaca) dengan proses hidrogenasi katalitik. Jurnal Ilmiah Teknik Kimia, 1(1), $1-3$. 